\title{
SMART AND PROTECTIVE SURVEYING OF HIDDEN MEDITERRANEAN HERITAGE
}

\author{
INTELIGENTNE BADANIA OCHRONNE \\ UKRYTEGO DZIEDZICTWA ŚRÓDZIEMNOMORSKIEGO
}

\author{
Zbigniew W. Paszkowski \\ Prof. PhD DSc. Architect \\ Author's Orcid number:0000-0002-7506-0185
}

West Pomeranian University of Technology in Szczecin, Poland

Faculty of Architecture

\begin{abstract}
In the Mediterranean area, there are hundreds of ancient cities that have ceased to exist, and millions of valuable parts of buildings and sculptures remain hidden or abandoned. This resource requires special care and protection. There is probably a much larger part of this resource, as yet unexposed to view, remaining to be discovered. A number of historic buildings remain underground or underwater, and are not properly protected against damage or robbery. Protected areas, with limited access due to the potential occurrence of ancient monuments underground or underwater, should be designated. In order to assess the range of occurrence of such monuments from bygone cultures, it is necessary to carry out specialized field studies. The author indicates that smart digital technologies, such as digital maps of the area, satellite and aerial photographs and electromagnetic geo-radar surveys, could be used for such research.
\end{abstract}

Key words: archaeology; architectural heritage protection; drones; Mediterranean area; smart city; urban development.

\section{STRESZCZENIE}

W rejonie Morza Śródziemnego istnieją setki starożytnych miast, które przestały istnieć, a miliony cennych części budynków i rzeźb pozostają ukryte lub opuszczone. Ten zasób wymaga specjalnej opieki i ochrony. Prawdopodobnie do odkrycia pozostaje jeszcze znacznie większa część tego zasobu, jeszcze nieodkryta. Wiele historycznych budynków pozostaje pod ziemią lub pod wodą i nie jest odpowiednio chronionych przed zniszczeniem lub rabunkiem. Należy wyznaczyć obszary chronione, do których dostęp jest ograniczony ze względu na potencjalne występowanie starożytnych zabytków pod ziemią lub pod wodą. Aby ocenić zasięg występowania takich zabytków z minionych kultur, konieczne jest przeprowadzenie specjalistycznych badań terenowych. Autor wskazuje, że do takich badań można by wykorzystać inteligentne technologie cyfrowe, takie jak cyfrowe mapy terenu, zdjęcia satelitarne i lotnicze oraz georadary elektromagnetyczne.

Słowa kluczowe: archeologia; drony; inteligentne miasto; obszar śródziemnomorski; ochrona dziedzictwa architektonicznego; rozwój miast. 


\section{INTRODUCTION}

The Mediterranean area is a very interesting area of exploration for lovers of ancient architecture. There are hundreds of ancient cities that have ceased to exist, and whose remains can be visited, instilling both nostalgia and admiration. However, many valuable buildings and their remains and sculptures still remain hidden. This hidden resource requires special care and protection. There is probably a much larger part of this resource, as yet unexposed to public view, remaining to be discovered. Historic ancient buildings or their remains are often hidden underground, covered by ruins, sand, mud or water. The major part of the world's oceans is still currently unexplored and many valuable artifacts, ancient ruins and long-forgotten ancient kingdoms have not yet been discovered. Many of these fabulous ancient relics of architecture are lying on the ground, not properly protected against damage or robbery.

The recognition of areas having hidden heritage resources, and the creation of heritage protection plans, would protect those areas against destructive development and, in the case of those monuments yet to be explored, against damage. In accordance with the principle of sustainable development, there is no need to discover and collect all those treasures of cultural heritage that are hidden from our eyes. The author is convinced that, using non-destructive survey methods, it is possible to identify underground and underwater heritage resources, without the need for expensive and long-term archaeological exploration. He presents methods of data acquisition and its elaboration, using digital methods. This data could be used to create plans for the protection of hidden heritage - in accordance with applicable legal regulations.

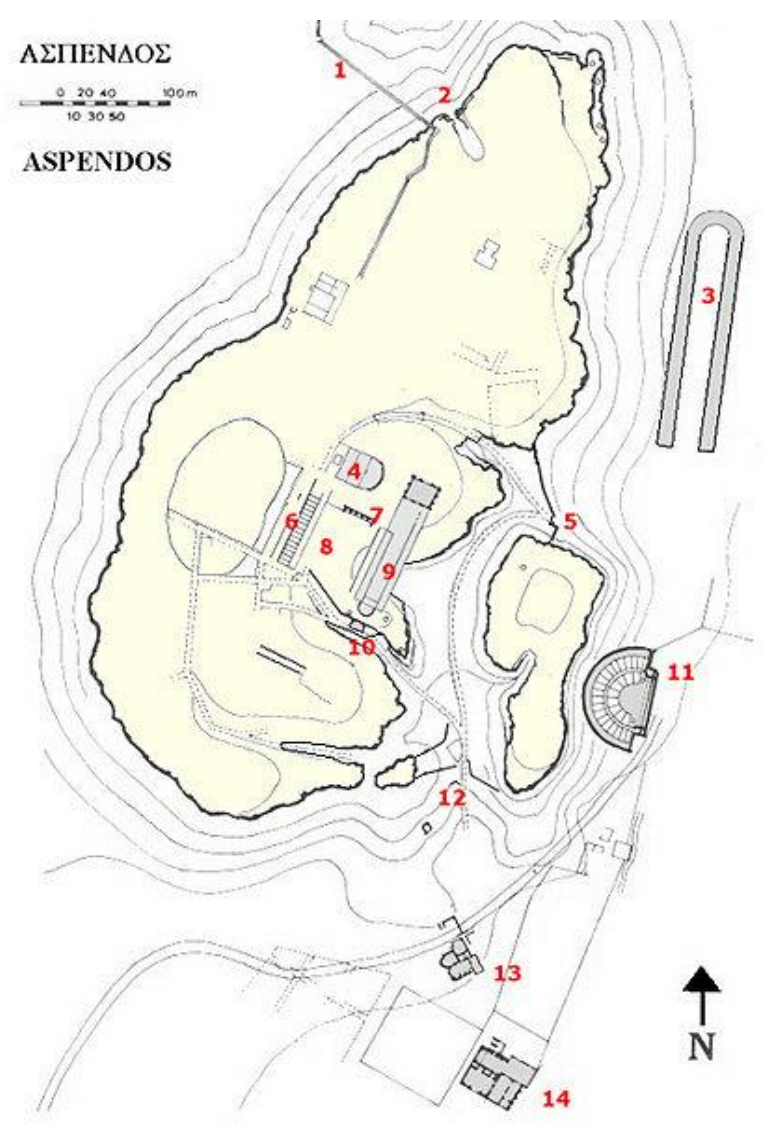

Fig. 1. The layout of the ancient city of Aspendos in Pamphylia (Turkey) illustrates how many undiscovered remains can still be found around the area. 1- Aqueduct, 2- Gate to the North, 3- Stadium, 4- Bouleuterion, 5- Door to the east, 6- Markethall, 7- Nymphaion, 8Agora, 9- Basilica, 10- Exedra, 11- Theater, 12- Gate to the South, 13- Bath, 14- Gymnasium. Source: Wessmann 2017 


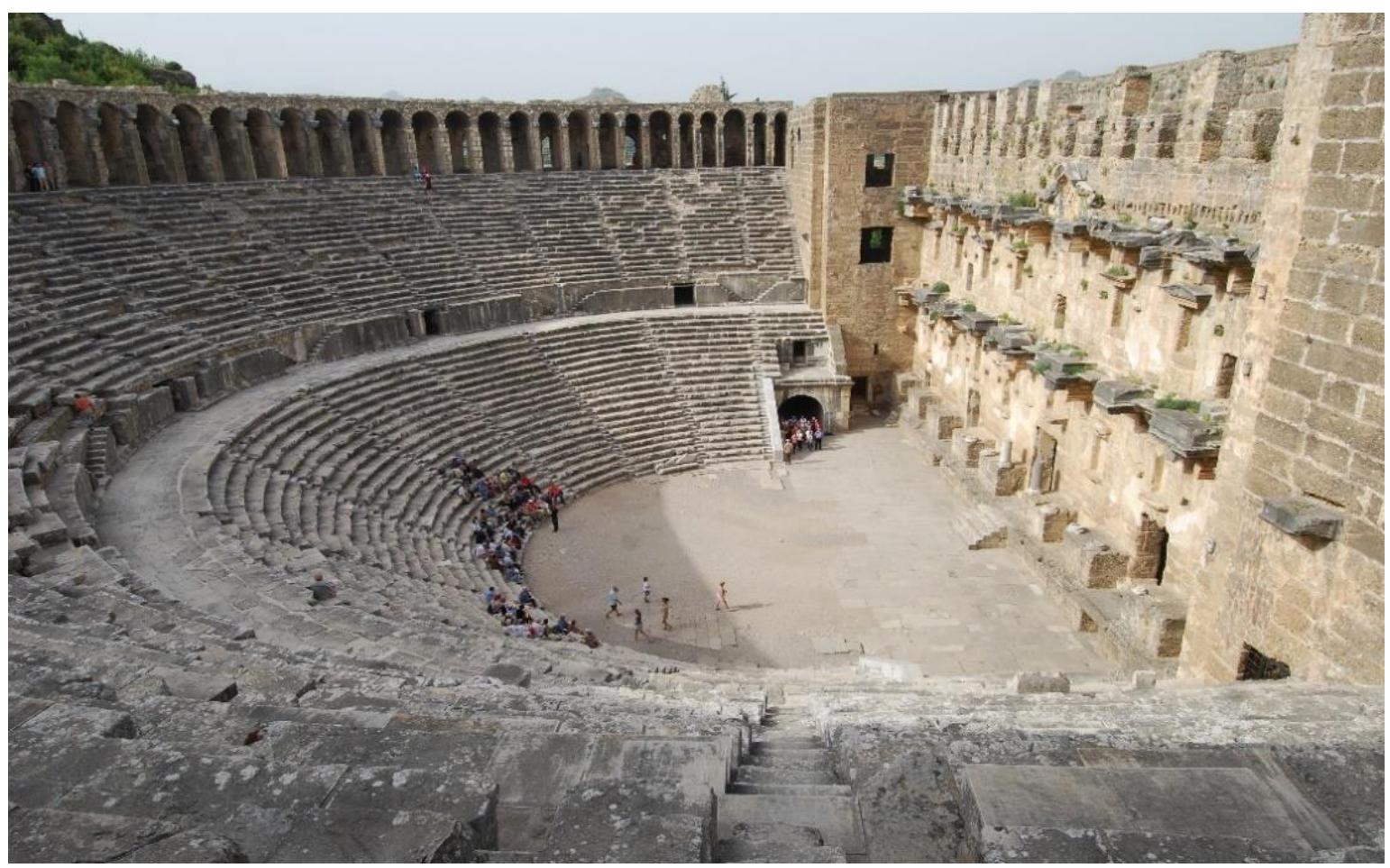

Fig. 2. The Roman theatre in Aspendos (Turkey), one of the best preserved treasures from Roman times. Its dimensions show how impressive the city must have been in ancient times. Source: author's photo

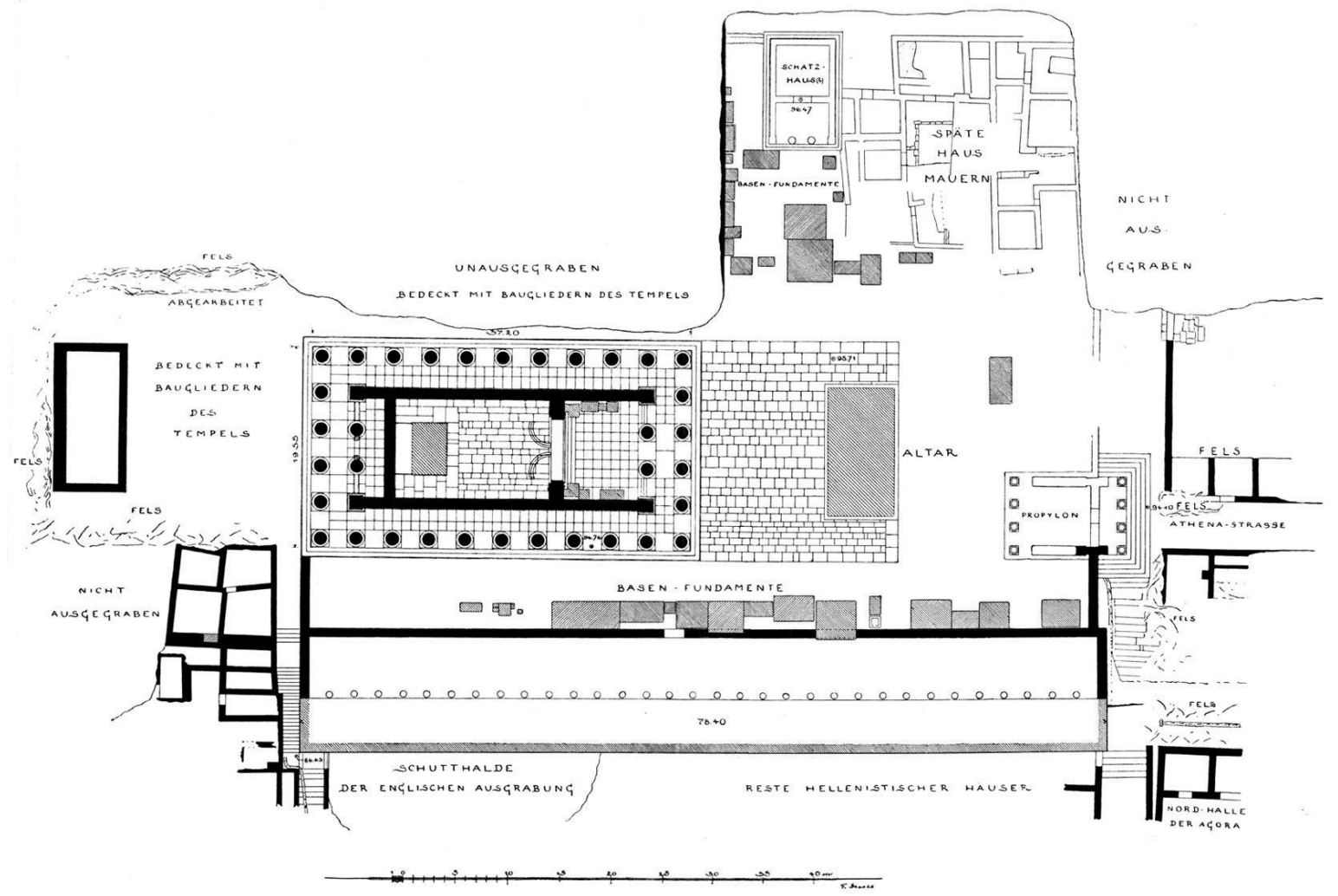

Fig. 3. Graphic reconstruction of the Athena sanctuary in Priene (Turkey). Source: Dietrich 2016. P. 313 

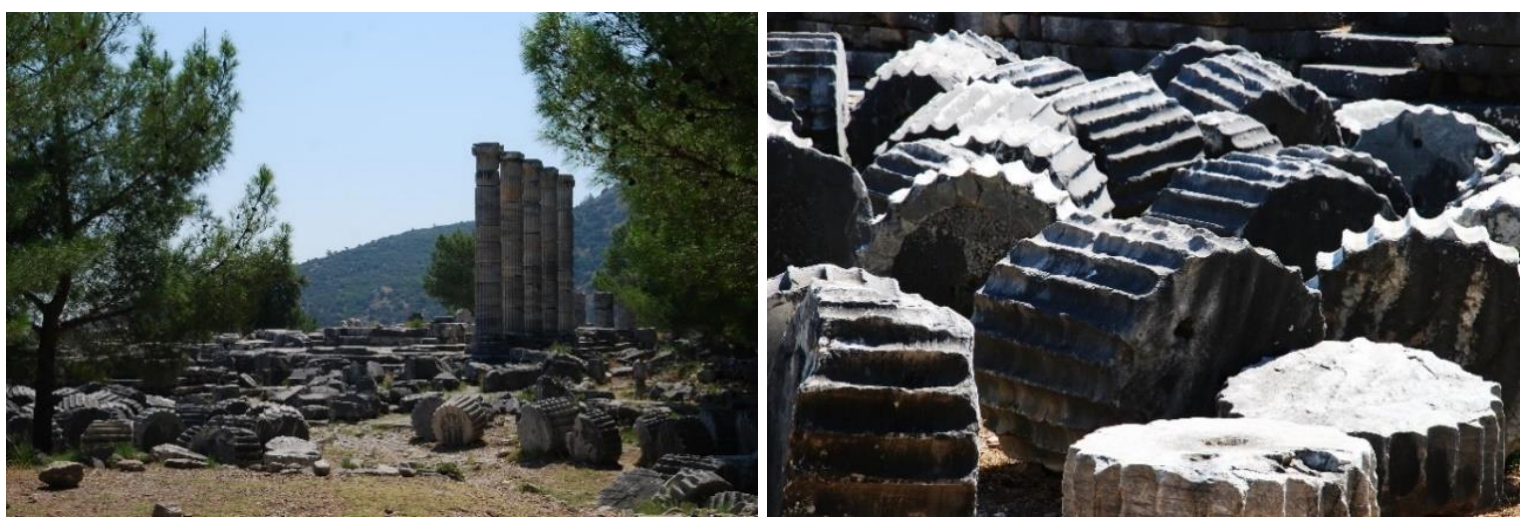

Fig. 4, 5. The unprotected remains of the ancient Greek lonian architecture of the Athena sanctuary in Priene. Source: the author's photos

In the years 2004-2016, the author had the opportunity to visit and explore the Asian part of the Aegean Sea area, an important part of ancient Greece and the Roman Empire. The ancient places and cities known today constitute just a small part of the architecture of the ancient world. The ancient world was composed of many cultures, of which many remains, ruins and other testimonies to its rich and extraordinary past remain, but many are still undiscovered. These resources, of both material and intellectual culture, have become the cradle of European culture. The European Union should exhibit more concern towards the saving and protection of these treasures of ancient architecture.

The basic impression left by all such abandoned, destroyed cities is the overwhelming vastness of these monuments - witnesses to the history of the civilization of mankind. Due to their ubiquitous presence in some countries in the Mediterranean region, they are perceived as something normal, universal, and even unnecessary, disturbing the functioning of the modern world. This impression can be felt especially in the archaeological areas of former Greek and Roman cities from the ancient period in Asia Minor, - in present-day Turkey, such as Miletus, Priene, Side or Termessos, but not only in such places. There are also - many other earlier remains and treasures of former local cultures, such as those presented at the Anatolian Museum in Ankara or the Yeşilova Höyük Neolithic Settlement Museum in Izmir. Along the Aegean coastline, one can find historic areas that, in contrast, are - in no way protected, with elements of architecture scattered over large areas. These elements, -of high historical, aesthetic and scientific value, are - subject to biodegradation and physical destruction. - This dramatic situation also prevails in a number of Mediterranean areas located in North Africa, due to the prevailing anxieties, armed conflicts and-destructive activities of criminal organizations against such ancient cultural heritage.

The research presented was undertaken in order to establish and foster - an interdisciplinary synergetic dialogue between those disciplines representing the emerging potential of technology - in the recognition and protection of urban heritage. Its focus on the largely unexplored field of Mediterranean cultural heritage should create an increased awareness of the hidden values of the heritage of the past, enable the advanced management of archaeological sites by communes, and also create perspectives for the sustainable and resilient development of those Mediterranean areas which have lost their historical identities and awareness. The author would also like to highlight the synergy of technology-enabled interdisciplinary research within the management of tangible and intangible potentials hidden in Mediterranean land, coastal and maritime areas. The research presented focused on building-up a logical, theoretical framework for potential future research tasks in the Mediterranean area and the encouragement of multidisciplinary teams to apply for research grants in the fields of the research, surveying and protection of hidden heritage. The study of preserved Mediterranean cultural heritage requires in-depth historical analyses, specialist research, and inter-branch and international coordination. The purpose of this article is to show that conducting research on a large area with historical potential requires the use of modern research and analytical methods. The author - highlights existing and functioning systems in this field of research. 

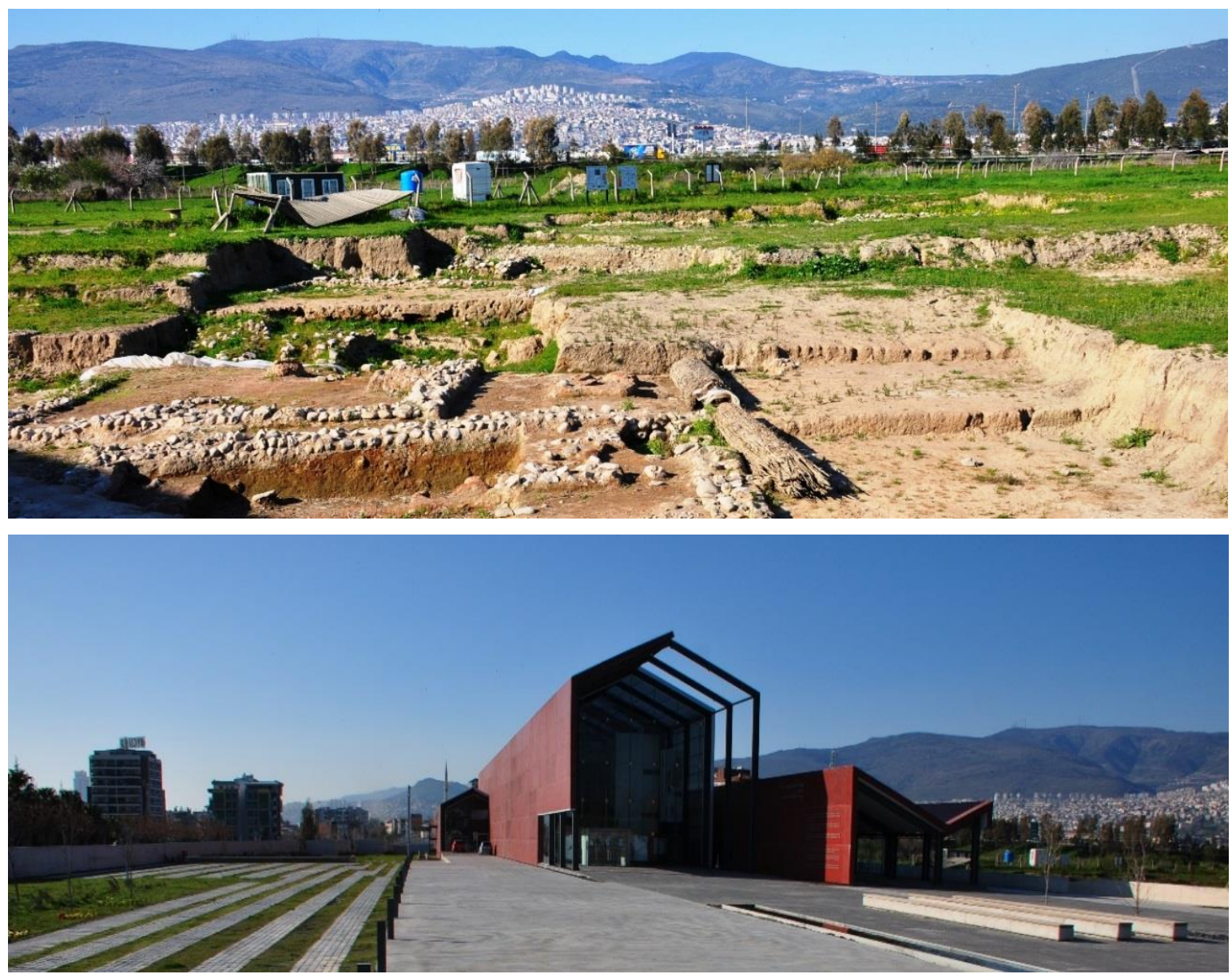

Fig. 6, 7. The archaeological excavations at Yeşilova (Izmir suburbs) and the discovery of the Neolithic settlement dated 6500 BCE, have stopped the urban sprawl of Izmir toward the East and caused the construction of a protected area, with the Yeşilova Hoyuk Neolithic Settlement Museum as an exhibition, educational and research building. Source: the author's photos

Fig. 8. Reconstruction drawing of the layout of the agora area in the

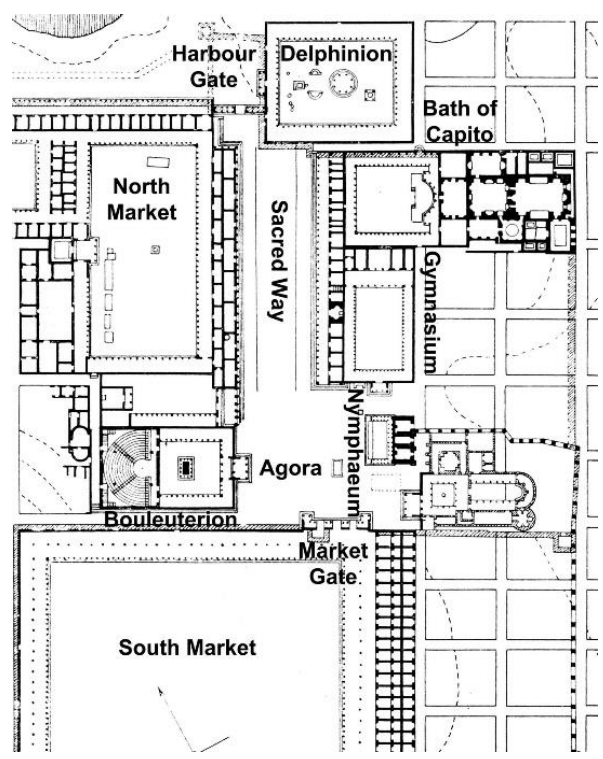
ancient city of Miletus. Source: Dietrich. 2016. p. 305 

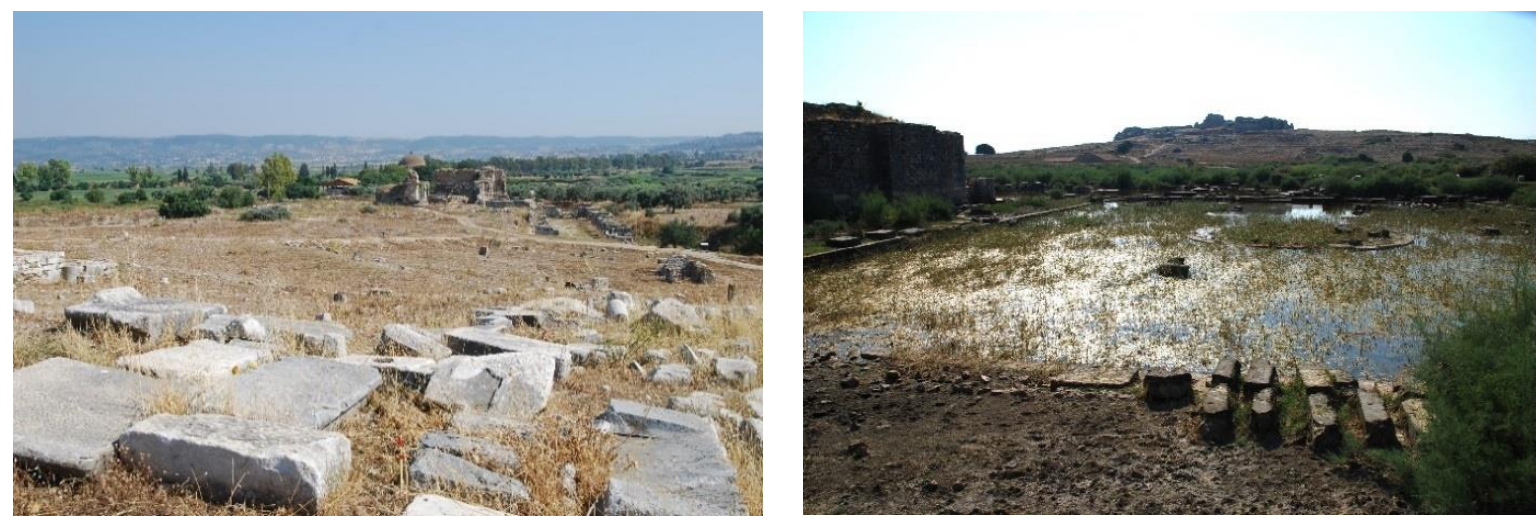

Fig. 9, 10. The remains of the vast, abandoned and ruined ancient city of Miletus (Turkey). A famous port city and important treasure of urban history, planned by Hippodamos. The archaeological area is freely accessible. A large part of the remains are not protected and have been damaged. Source: the author's photo.

For the most effective and comprehensive conducting of archaeological and architectural research into Mediterranean culture heritage, it is absolutely essential to apply new techniques of detection, measurement, inventory and analysis as part of the integrated research activities undertaken. In particular, new techniques of archaeological detection allow for the conducting of non-destructive testing within large areas with archaeological potential. Contemporary technologies allow data acquisition from the air, without the need for performing extensive ground excavations using archaeological methods. This is particularly important in order to protect the unknown or unrecognized value of cultural areas and objects hidden underground or underwater. In order to improve the security of the material resources of the cultural heritage of the Mediterranean, it is necessary to define both the resources that should be protected and the types of analyses and methods that should be used to identify such resources, as well as their location and means of protection.

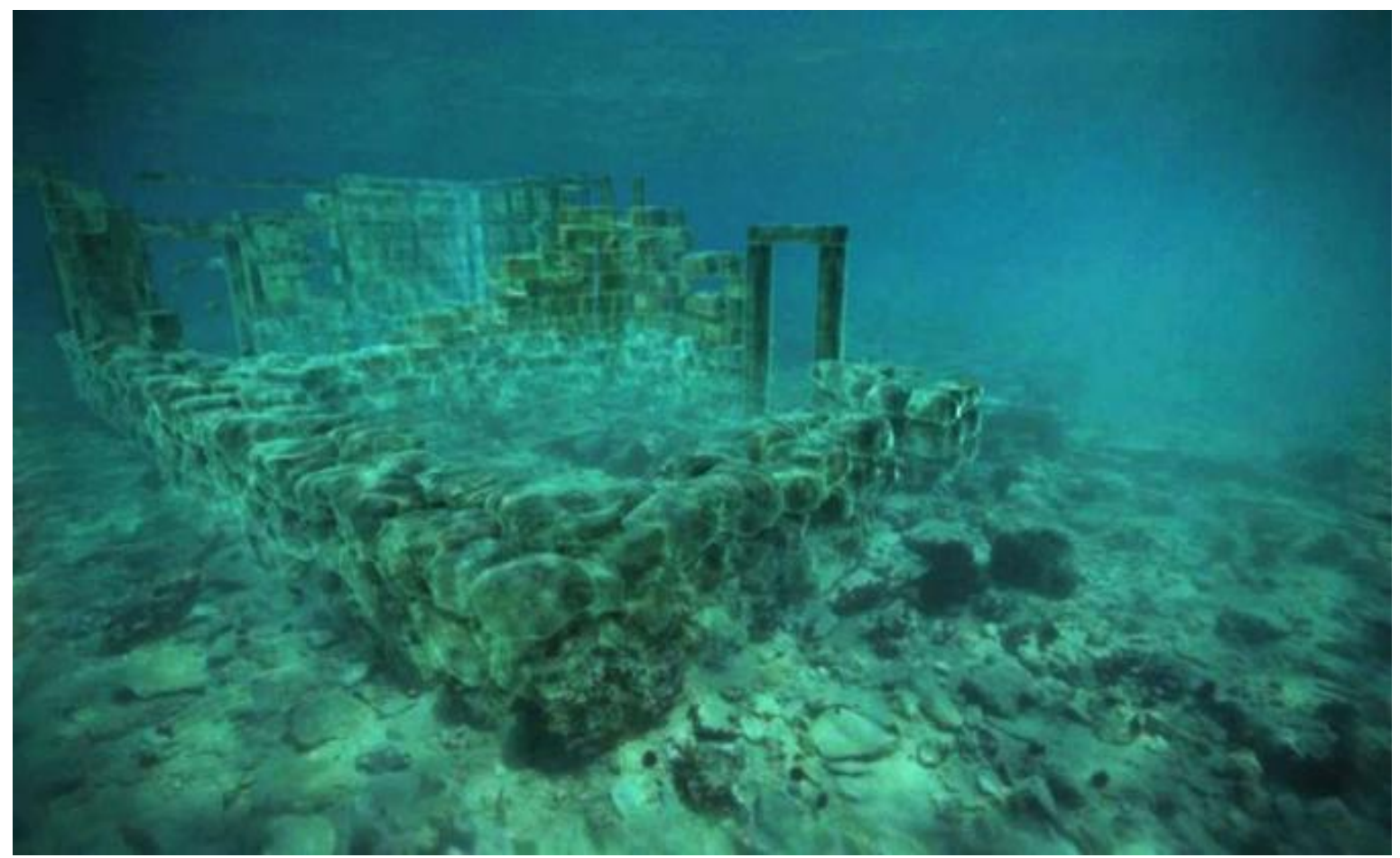

Fig. 11. The sunken city of Pavlopetri. Source: The oldest submerged 2016 
The main goal of the research undertaken is to identify and effectively protect those areas at risk against damage or non-reflective urbanization. The basic method that the author proposes in order to achieve this goal is the introduction of smart technologies to the process of archaeological research, using digitalized tools, such as aerial detection, surface inventory and resource assessment, as well as the collation of research results into an internet-based database system. In order to illustrate the method of smart surveying, the author presents below two examples of different research being conducted by specialists in this field, with the use of a LiDAR detection system integrated onto an SUA, the methods of research used, and the results achieved. The first case study refers to a surface examination in order to discover traces of historical human activity an area, while the second case describes the use of innovative technologies for data acquisition, in order to introduce an integrated surveillance and security system for the protection of a valuable archaeological site.

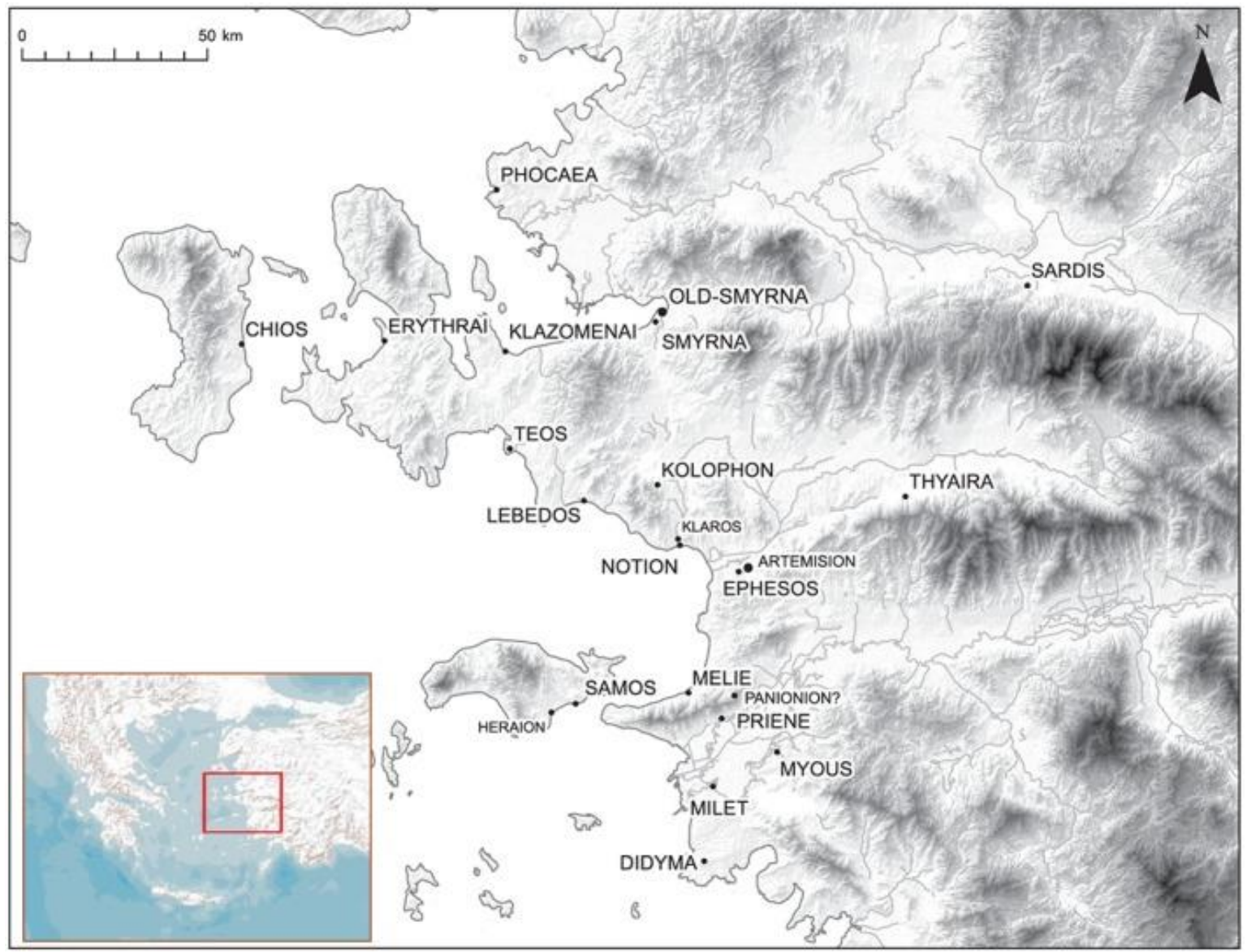

Fig. 12. The Eastern Aegean Coast with ancient Greek cities. Source: Grammer B._et al, 2017. p. 312.

\section{CASE STUDY}

\subsection{Case Study 1. LiDAR Survey of the Ancient City of Kolophon}

Kolophon is an lonian city located near the western coast of Turkey, $35 \mathrm{~km}$ south of Izmir. In ancient times, the city was a member of the league of 12 lonian cities and was the only one not situated directly on the coast. The city can be reached from the coast after some $16 \mathrm{~km}$, along the narrow Ahmetbeyli (ancient Ales) valley. During the Geometric period, the distance to the coast might have been about $1.5 \mathrm{~km}$ shorter. The city was closely aligned with the Apollon sanctuary of 
Klaros and later with the port city of Notion. The city was known for its wealth and the quality of its cavalry forces in the Archaic period. After a series of violent struggles with the Lydian Empire, its importance diminished. Kolophon was conquered by the forces of Lysimachus in Hellenistic times. After an unsuccessful attempt at resistance, the polis was dissolved, and its population transferred to Ephesus. The Kolophon case study is an example of the methodological approach. The Kolophon Project was a part of a project (P-24763) funded by the Austrian Science Fund (FWF), hosted by the Department for Classical Archaeology at the University of Vienna. The project leader, Erich Draganits, was additionally funded by FWF project P-28410-G25. The completion of the survey project in Turkey was achieved in cooperation with the Mimar Sinan University of Istanbul. The survey method used was LiDAR. The Kolophon Project resulted in the discovery, on the southern slopes of the mountain, of anthropomorphic elements, which are probably graveyards with tombstones. (Grammer .et al, 2017)
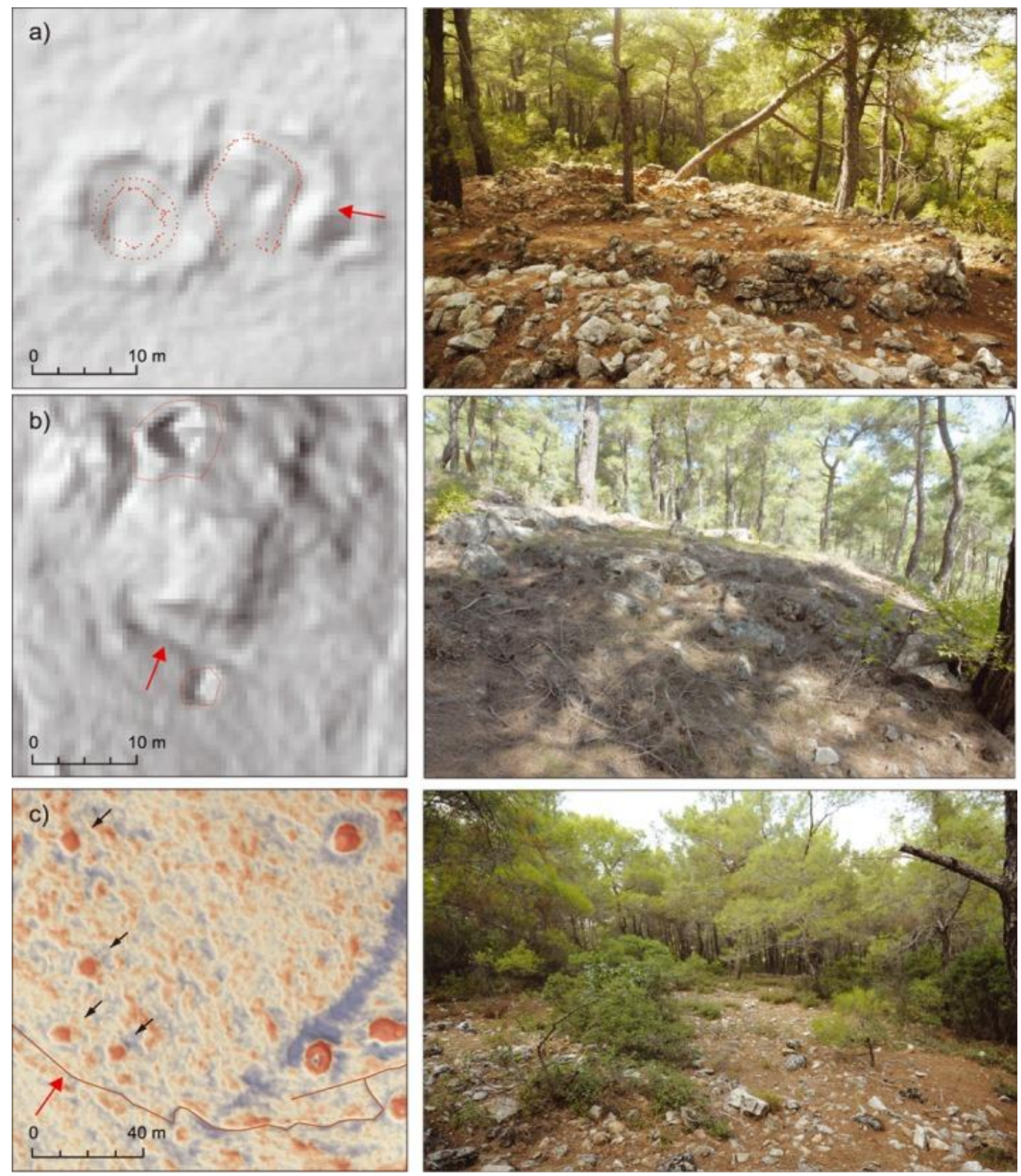

Fig. 13. LiDAR output survey maps in comparison with real situations in photographs.

Source: Grammer .et al, 2017, p. 329 
2.2. Case Study 2 - Analysis and data acquisition methodology based on SUA for the implementation of the Internet of Everything to smart archaeological areas (The lonian Dodekapolis)

For the implementation of the proposed methodology for analysis and data acquisition, the ancient Roman city of 'Ocriculum', founded in about 168 A.D., located in Otricoli (the Umbria Region), and sited on a hill, was chosen. At the end of the Republican Era, 'Ocriculum' was relocated to the plain below the hill, at a large bend of the River Tiber. The city played an important port function, exporting olive oil to Rome by waterway. The most important monuments of ancient architecture are still to be seen there, such as the amphitheater, the thermal baths (Fig. 20), the forum area, the mausoleum, substructures and other ruins of buildings. The site is crossed by the Flaminia Way, which contributed to the development of trade, making the city of Ocriculum an important centre, with a strategic function, between Umbria and Sabina (Conciaioli 2000).

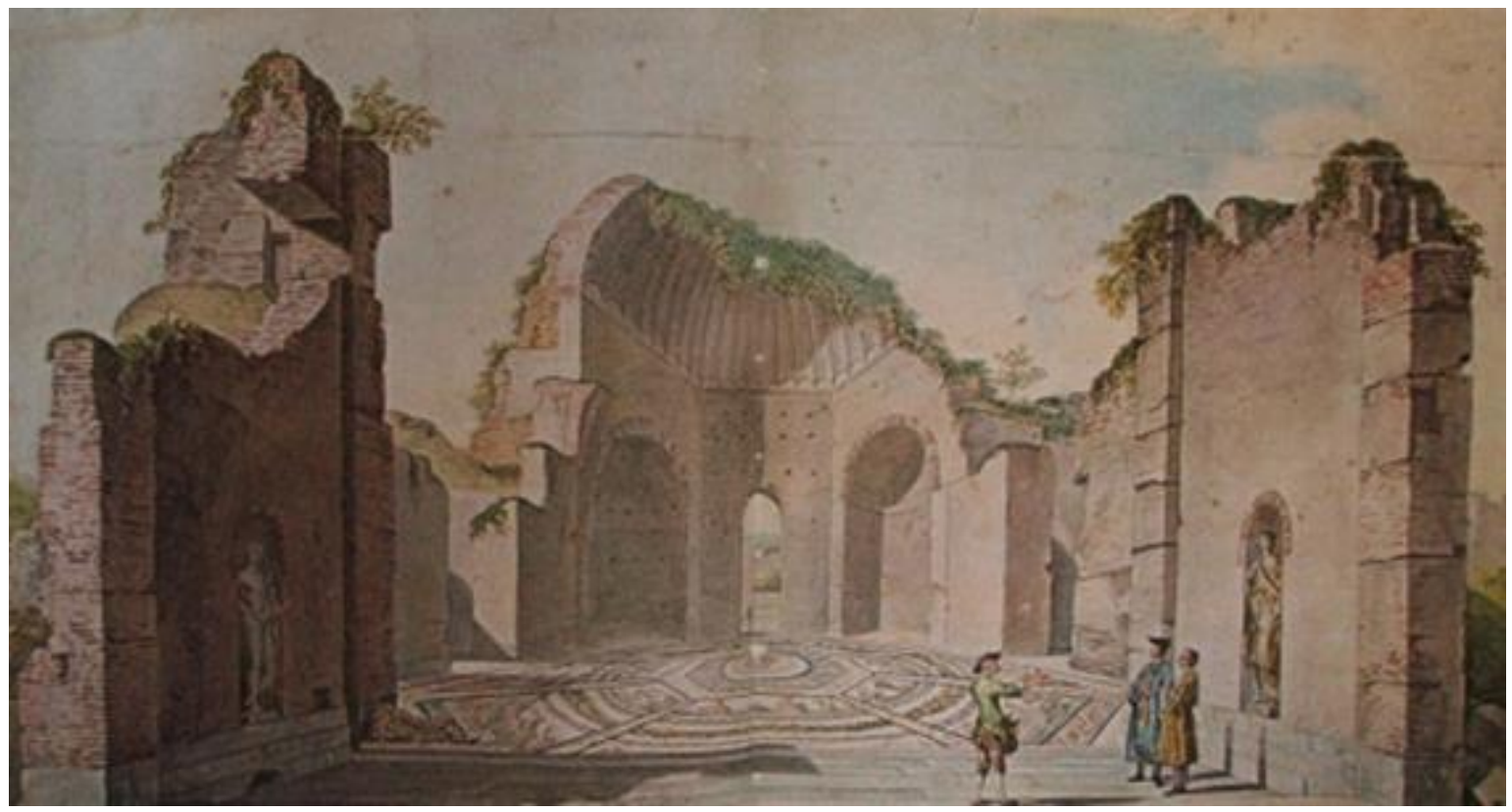

Fig. 14. The ruins of the Roman baths in Ocriculum with the famous mosaic, a drawing of Pannini (1784). Source: Hay Sophie. 2013

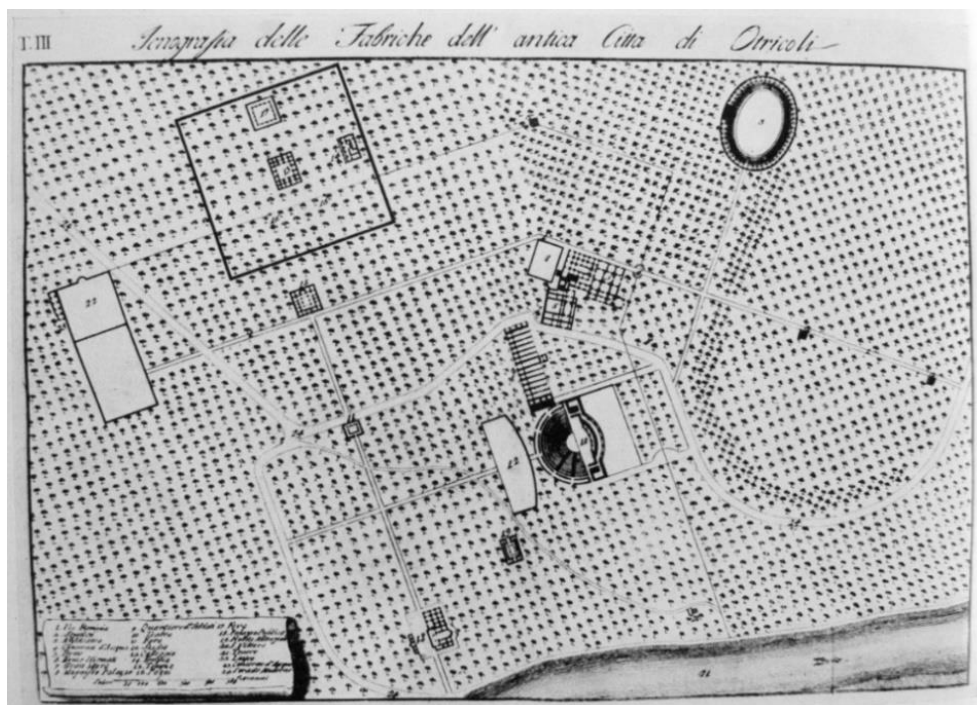


The aim of this case study project was to introduce an integrated surveillance and security system, composed of innovative technologies, linking the Internet of Everything to people, data, things, information and processes (Garzia, Lombardi, Lucca 2018). Initially, a detailed analysis of the fundamental information regarding the history, geology and geomorphology of this site was performed. The most specific data was delivered by means of flying drones, which took ortho-photos, in order to make a digital elevation model of the terrain, and various other analyses, such as: thermal, vegetation, multi-spectral, vegetation index maps and 3D models of the ruins. The results of the project were the evaluation of different security systems and risk analyses of the archaeological area, the presentation of the integrated ADAM-FD system and proposals for minimizing the cost of installation of the security system.

Both cases reveal that smart technologies can already be applied to different tasks within archaeological data acquisition and site protection projects and are able to deliver astonishing results, according to these new findings. It is also obvious that this trend will develop in the future.

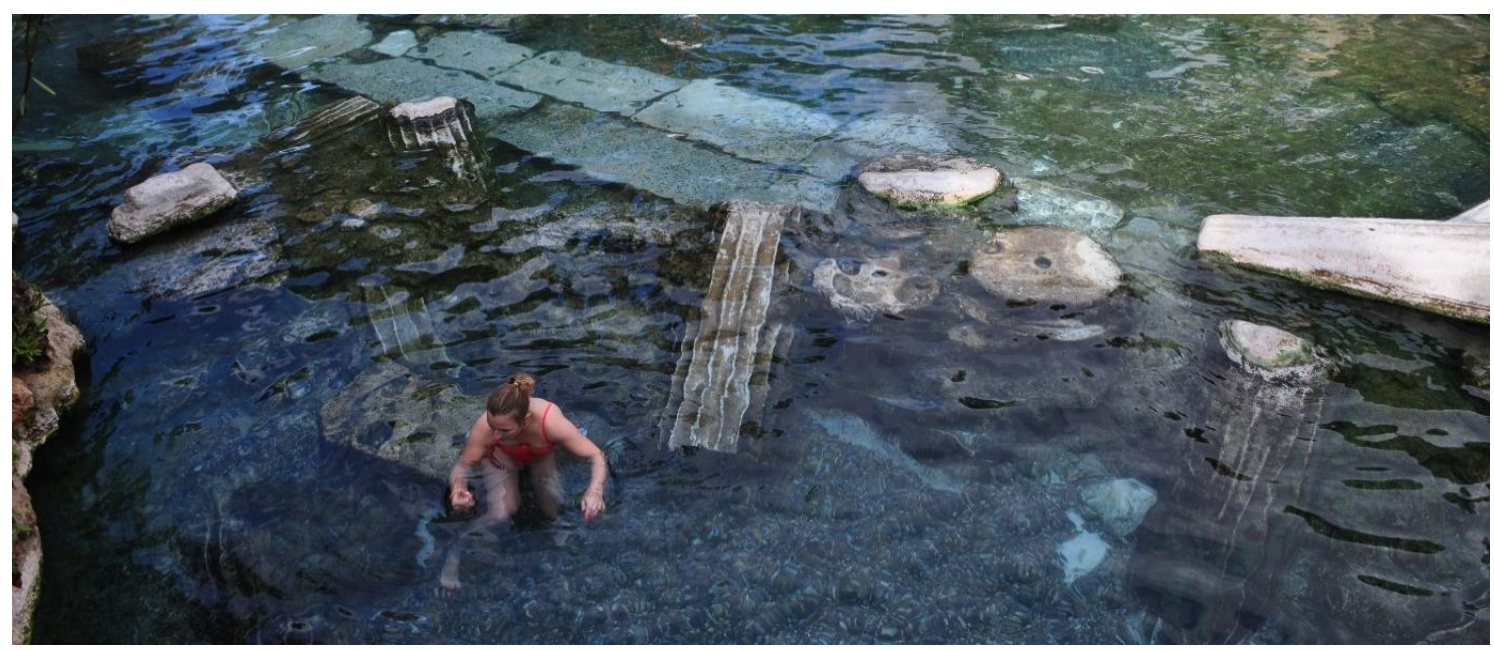

Fig. 16. Underwater architectural elements in Hierapolis (Pamukkale) in Turkey. Source: author's photo

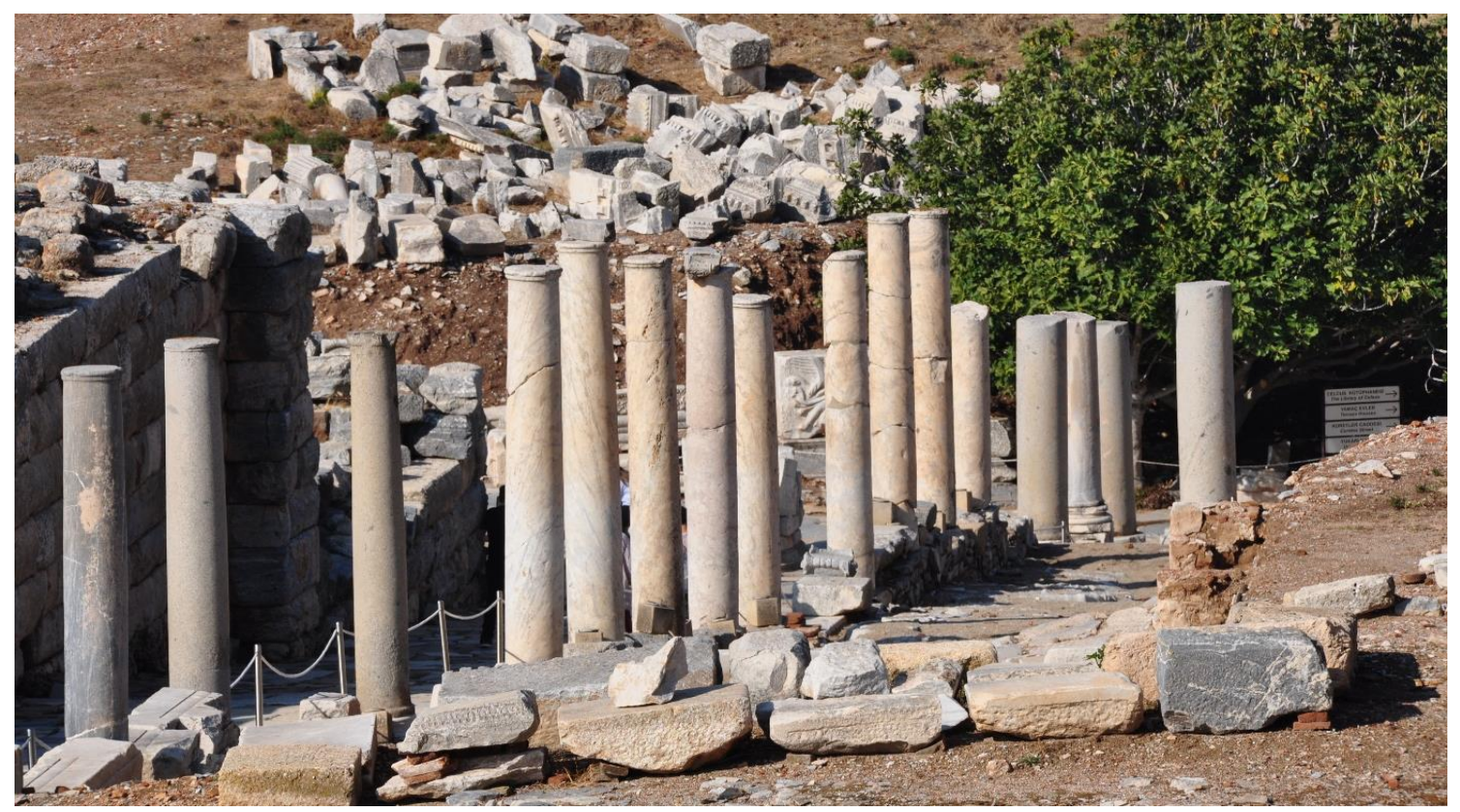

Fig. 17. Anastylosis of a street colonnade in Ephesus (Turkey). Source: author's photo 


\section{RESULTS}

The result of the author's study has been the widening of knowledge and competences regarding the possibility of the application of new tools and analytical methods to the survey and evaluation of those archaeological sites potentially threatened by different risks of destruction. The author's studies have resulted in a comprehensive description of the great number of tasks still to be done in the Mediterranean cradle of European civilization. The scope of these tasks, together with their interrelation and synergies, has been illustrated in the form of graphic presentations as well as in tables and lists. The following tasks in field research and in computer analysis are planned:

- recognition of areas with hidden architectural heritage resources

- delimitation of protected areas with discovered or presupposed architectural hidden heritage

- definition of protective methods for these areas against various destructive threats, including damage related to the poorly-planned urban development of cities and roads

- identification of underground and underwater heritage resources, using non-destructive testing methods, without the need for costly and long-term traditional archaeological research

- collation and processing of project outcomes and information obtained on a unified digital platform in the form of information available for further use and development. This information should be helpful mainly as study material for institutions defining the principles and possibilities of land use, spatial planning offices, international ancient monument research bodies, and district councils.

The above-listed results can be achieved only under several known (and many more unknown) conditions, such as obtaining of legal permits to perform survey flights and archaeological ground excavations, a calm political situation, especially when the research team comes from abroad, financing of the equipment, hardware and dedicated software, personnel and performance costs, as well as insurance for staff members and locals involved, and for equipment.

Achieving these results is only possible when a minimum of the following most important research tasks have been carried out. Below is a list of the basic scientific tasks which should be considered before site penetration:

1. Identification of areas with hidden and endangered heritage resources

2. Creation of heritage protection plans that would protect areas from destructive development, including as yet unexplored architectural and artistic objects, before they are further damaged

3. Creation of databases of identified underground and underwater heritage resources

4. The use of non-destructive testing methods, reducing the costs of labour-intensive, specialized and long-term archaeological research carried out using conventional methods

Fig.18. A diagram of the main project research tasks. Source: the author.

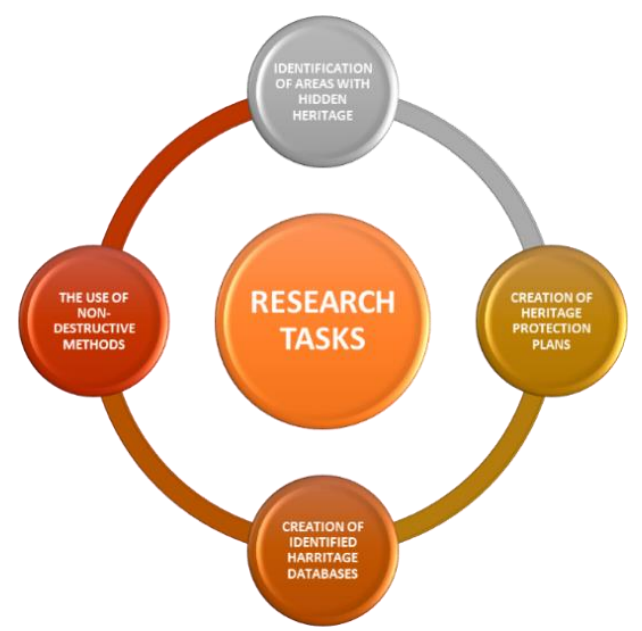


The information should be collated on a unified digital platform and made available either with limited or universal access - depending on the sensitivity of the data collated and the methods adopted for the protection of the ancient heritage being analyzed. This data could be useful for local authorities, spatial planning institutions and historical conservators. This would allow for a better definition of areas that could be built upon and developed, as well as those areas in which detailed archaeological research could be carried out.

\section{DISCUSSION}

From the perspective of previous studies on the architectural heritage of the Mediterranean area, the described problems and threats resulting from this research and the task of protection, seem to be much wider and harder than expected. New tools, like LiDAR or SUA, are giving a completely new perspective for to archaeological research, and new possibilities of for the comprehensive surveying of vast areas, which would have been impossible using traditional archaeological methods. On the other hand, these tools, if used for $₹$ criminal purposes, could create many more problems for heritage protection. Therefore, there seems to be a serious need of for aerial protective measures of hidden heritage areas and this should be widely developed. In relation to this situation, tools for surveillance and protection, similar to those used for scientific research, should be considered.

It sometimes seems that the above-mentioned universality of archaeological sites, and the classical form of historic buildings in some areas, weakens the interest of residents and local authorities in protecting them against threats and damage. There are still many valuable archaeological areas that are devoid of any security or access control. There are also areas that are unprepared for tourist purposes, and consequently do not receive much concern in terms of their protection. This happens due to difficulties in accessibility or to a total lack of access or tourist infrastructure or to a lack of spectacular features, a lack of recognition, or the lack of a historical descriptive explanation of ruined objects, etc. If we consider the timeless character of these preserved fragments of ancient culture and architecture and their value, both today and in the future, we can clearly see the urgent need to of preserving this heritage as widely as possible for future generations. Today, this task is a special challenge, when considering those new and extremely serious threats which are emerging, including the following, in particular:

- the unrestrained development of leisure and cultural tourism, connected with the commercialization and impoverishment of cultural heritage

- the urban development of cities and a circular urban transport system that covers areas with new archaeological potential with new developments

- natural phenomena, such as seismic shocks and other disasters resulting from their location in this geographical latitude and from natural hazards in the Mediterranean area (such as floods, fires, volcanic eruptions, earthquakes, landslides, desert sands, etc.)

- the phenomena of weather anomalies resulting from climate change (e.g. temperatures below $\left.0{ }^{\circ} \mathrm{C}\right)$

- cultural, religious and armed conflicts, which are a very real threat to many surviving material cultural artefacts

These threats can be caused by the "activity" of certain interested parties or by non-protective, "lack of care" abandonment and the slow process of erosion.

To encourage awareness of these threats, the author has listed the most frequent threats to hidden architectural heritage.

Table 1. Threats to hidden architectural heritage. Source: the author

\begin{tabular}{cccc}
\hline No. & The problem & Description of the problem & Possible solutions \\
\hline I & & THREATS DUE TO ACTIVE HANDLING & \\
\hline 1 & recycling (re-use) of historical & building elements of historical & aerial perimeter protection and
\end{tabular}




\begin{tabular}{|c|c|c|c|}
\hline & materials, elements & $\begin{array}{l}\text { buildings from existing ruins or from } \\
\text { underwater sites are excavated } \\
\text { and built into new constructions }\end{array}$ & $\begin{array}{l}\text { surveillance of the valuable historic sites, } \\
\text { education about the historic value of } \\
\text { architectural remains }\end{array}$ \\
\hline 2 & $\begin{array}{l}\text { introduction of new buildings } \\
\text { into archaeological areas }\end{array}$ & $\begin{array}{l}\text { unconscious or deliberate } \\
\text { construction of new-build structures } \\
\text { over existing potential } \\
\text { archaeological areas }\end{array}$ & $\begin{array}{l}\text { local, communal control of building sector } \\
\text { activities and introduction of strict rules (a } \\
\text { conservation of monuments law, if not } \\
\text { present) concerning building exclusion on } \\
\text { archaeological sites }\end{array}$ \\
\hline 3 & $\begin{array}{l}\text { deliberate destruction of histor- } \\
\text { ic buildings }\end{array}$ & $\begin{array}{l}\text { religious fanaticism, war activities, } \\
\text { incidental vandalism }\end{array}$ & $\begin{array}{l}\text { better surveillance, political influence, } \\
\text { physical protection, scanning and digital } \\
\text { storage of all heritage monuments at risk }\end{array}$ \\
\hline 4 & $\begin{array}{l}\text { theft of elements of ancient } \\
\text { architecture and art }\end{array}$ & $\begin{array}{l}\text { illegal trade in remains and } \\
\text { architectural and artistic objects }\end{array}$ & $\begin{array}{l}\text { political and governmental control over the } \\
\text { black market of in archaeological objects } \\
\text { scanning and digital storage of all heritage } \\
\text { monuments at risk }\end{array}$ \\
\hline 5 & $\begin{array}{l}\text { creating imitations of historical } \\
\text { objects, scientifically unrea- } \\
\text { sonable reconstructions or } \\
\text { anastyloses }\end{array}$ & $\begin{array}{l}\text { reconstruction of ancient structures } \\
\text { or historic buildings with } \\
\text { insufficient information on the } \\
\text { outlook and structure, creating } \\
\text { "fake historic buildings", } \\
\text { exchanging valuable structures } \\
\text { with their caricatures }\end{array}$ & $\begin{array}{l}\text { More advanced building permission } \\
\text { procedures, governmental control of } \\
\text { building sector in archaeologically } \\
\text { interesting areas, early education, } \\
\text { information, manuals, and training of } \\
\text { architects and building staff }\end{array}$ \\
\hline 7 & $\begin{array}{l}\text { over-exploitation of } \\
\text { archaeological areas by } \\
\text { tourism }\end{array}$ & $\begin{array}{l}\text { interesting areas and } \\
\text { archaeological sites are visited by } \\
\text { thousands of cultural visitors (e.g. } \\
\text { cruise ship tourists) }\end{array}$ & $\begin{array}{l}\text { limitation and redistribution of tourist flow, } \\
\text { organisation of tourist paths, full and } \\
\text { comprehensive, multilingual instructions } \\
\text { for behaviour at a heritage site; provision } \\
\text { of tourist facilities (toilets, rest rooms, } \\
\text { souvenir shops), named tickets, high } \\
\text { penalties }\end{array}$ \\
\hline II & \multicolumn{3}{|c|}{ THREATS DUE TO “LACK OF CARE” } \\
\hline II/1 & $\begin{array}{l}\text { lack of aerial protection of } \\
\text { ancient heritage }\end{array}$ & $\begin{array}{l}\text { remains of architectural heritage } \\
\text { are spread around large areas } \\
\text { without no any protection; } \\
\text { not insufficient monumental } \\
\text { conservation protection and } \\
\text { building control over valuable } \\
\text { archaeological areas; no support or } \\
\text { protection measures for tangible } \\
\text { and intangible heritage; } \\
\text { unauthorised access to heritage }\end{array}$ & $\begin{array}{l}\text { preventive aerial research, introduction of } \\
\text { archaeological protected zones in planned } \\
\text { and real situations; control of access, } \\
\text { smart visual protection over valuable } \\
\text { areas (CCTV) }\end{array}$ \\
\hline II/2 & consent for biodegradation & $\begin{array}{l}\text { due to lack of care, biodegradation } \\
\text { processes are } \\
\text { irreversibly destroying heritage } \\
\text { remains }\end{array}$ & $\begin{array}{l}\text { undertaking a survey of heritage at risk, } \\
\text { applying for "rescue funds", voluntary } \\
\text { action, education, protective care }\end{array}$ \\
\hline $11 / 3$ & $\begin{array}{l}\text { lack of protection against } \\
\text { climatic influences }\end{array}$ & $\begin{array}{l}\text { changing climate conditions are } \\
\text { enlarging the scope of threats } \\
\text { against architectural and } \\
\text { archaeological structures and } \\
\text { remains }\end{array}$ & $\begin{array}{l}\text { Surveying and early recognition of climate } \\
\text { threats, preventive measures, } \\
\text { monumental protection focused on } \\
\text { ensuring heritage safety }\end{array}$ \\
\hline
\end{tabular}

The issue with respect to the widespread conducting of detection tests is the fear of threats arising from the dissemination of information about archaeological resources or their potential location, which may encourage unauthorized persons to try to penetrate them. Of course, such a threat always exists. Nevertheless, if positive results were obtained from the exploratory research, it would be necessary to implement appropriate forms of protection for the area, to prevent it from being penetrated and its value as a monument being destroyed. All countries of the Mediterranean area have introduced laws regarding conservation protection. It is not the aim of this article to discuss the provisions of these laws or their effectiveness. Nevertheless, the author would like to highlight new possibilities of law enforcement, through preventive research and the protection of areas at risk by the use of new devices and advanced software. 


\section{MATERIALS AND METHODS}

The old archaeological methods of land surveying were based in general on literature, descriptions of incidental findings and casual findings. The new methods presented allow the systematic surveying of land and water areas, which, in the Mediterranean basin, is extremely important. Those historic sources, excavation reports and archaeological findings still play a crucial role in the appropriate selection of areas to be surveyed, and the expectation grade of findings.

Within the field of architectural heritage research, there are many sources of materials, which can and should be applied to initial site-related research, such as previously-developed cartographic, physiographic and orthophotographic resources (The lonian Dodekapolis) or research descriptions of various kinds. These starting materials are either free or require registration and paid consent for use. There is the possibility and, at the same time, the need, to implement methods for identifying and designating heritage protection areas using new SMART methods, based on modern GIS technologies and methods of surveying. A satellite detection and positioning system allows for the very precise location of identified objects and area boundaries. In general, these methods can be summarised as:

- carrying out a broad plan of identification and an inventory of areas with potential archaeological value;

- creation of protected archeological and cultural areas (parks), and excluding the possibility of implementing infrastructural, residential, tourist and other investments in their vicinity;

- analysis of the potential value of isolated archaeological and cultural parks, through nondestructive testing carried out from the air and in situ;

- introduction of physical protection (fences, barriers, etc.), monitoring systems and legal security;

- correlation of protected areas with spatial planning, in order to exclude those areas from the possibility of interference from new buildings and infrastructural investments.

There are several SMART methods that can be used within the area of archeological and architectural detection, including:

- digital satellite maps, aimed at recognizing the topography of an area;

- aerial photography with high resolution;

- infrared photography;

- electromagnetic geo-radar examination.

Some of these methods, such as aerial photography, infrared photography, and laser flight detection have already been widely used for years. The development of this technology has allowed for more precise images to be achieved, for the correlation of various methods of measurement and imaging, and for more precise processing of the collected material. As a result, it is possible to obtain effects that could never have been dreamt of in the past. Another important aspect of these methods is the appropriate interpretation of the research results and their comparison with in-situ archaeological research, in order to confirm the finds identified.Research using SMART methods can be carried out both in the field and in research laboratories, using the latest achievements in the field of detection of underground and underwater objects and using high-performance computer equipment, as well as programs for processing image data and scanning with point clouds. In "threatened areas", the following preventive measures are necessary:

1. Search measures - these are carried out when historical records are known, but the location of objects or development units is unknown;

2. Verifying measures - these relate to areas on urban development plans, initially intended for the development or construction of infrastructure. These areas must be analyzed for the presence of historical objects in their vicinity;

3. System measures - these involve systematic research into a specific area, a separate area or island, in order to determine the occurrence of objects of potential archaeological value;

4. Protective measures - these consist of defining those areas of potential archeological value that should be covered by special protection, in order to prevent them from being destroyed. 
Fig. 19. The scheme of preventive measures in threatened areas. Source: the author.

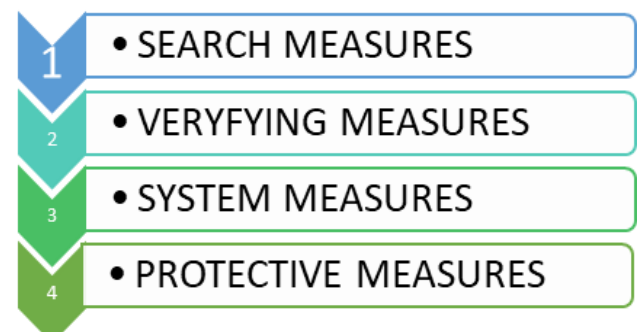

The exploration of the potential of archeological resources affects various areas of nature. These areas can be systematized, depending on their relation to urbanized areas, as shown in Table 2.

Table 2. System of defining hazards and prevention measures. Source: the author

\begin{tabular}{|c|c|c|c|}
\hline No. & Type of terrain & Type of threat & Type of measures \\
\hline 1 & A terrain with a high degree of urbanization & A high risk of archaeological potential & $\begin{array}{l}\text { search, verifying, } \\
\text { protective }\end{array}$ \\
\hline 2 & Areas in the area of urban expansion & High risk of archaeological potential & $\begin{array}{l}\text { search, verifying, protec- } \\
\text { tive }\end{array}$ \\
\hline 3 & $\begin{array}{l}\text { Areas of historical urbanization, not used } \\
\text { today }\end{array}$ & The threat of protective vandalism & verifying, protective \\
\hline 4 & $\begin{array}{l}\text { Non-urbanized areas with potential historical } \\
\text { value }\end{array}$ & $\begin{array}{c}\text { Low level of exploration and systemic } \\
\text { threats }\end{array}$ & system, protective \\
\hline
\end{tabular}

The basic conditions for undertaking research activities must be:

- obtaining the appropriate formal and legal consents and permits from local authorities to conduct aerial examinations and spot tests in the field of activities;

- establishing a material and financial schedule of research works, i.e. determining the basic scope of the research, its duration and a valuation of all related costs;

- obtaining financing appropriate to a fixed cost estimate;

- ensuring safety of access to the areas being studied throughout the research period - especially in the case of nearby military operations, as well as those threats resulting from terrorist activities;

- checking, by means of a safety assessment, the atmospheric and seismic conditions prevailing in the area of research, during the period of the planned research works.

The range of research for objects of potential archaeological value can extend over a large area. Therefore, laser detection from the air is used for this type of activity. Detection from the air can be carried out using airplanes with a set of devices or drones adapted for this purpose. The miniaturization of photographic and scanning devices means that airborne tests are increasingly being used.

Research into the area of the detection of architectural objects has been carried out many times and there have been a number of successes. An analysis of the research already carried out has been extremely helpful in defining the research program and the selection of the type of equipment for the planned research works. LiDAR is the leading aviation research device in this field. A device enabling the implementation of this visualization method of an area is attached to the fuselage of an aircraft. LiDAR technology can mainly capture underlying terrain, which is not feasible with aerial photogrammetry because of vegetative cover. As a result, high-density point clouds can be obtained across vegetated areas and used for the derivation of digital ground surface and canopy height models (Pleiades project). However, LiDAR interpretation in archeology is only about 
15 years old and its methodological and theoretical background is still under discussion. A central concern is how to derive archeological information from LiDAR data. At the beginning of any interpretation of LiDAR data, the research goal must be defined. Further steps will need to be determined in relation to this research question.

Of particular interest is the use of drones for survey purposes with LiDAR technology. According to Peppa, drones or SUAs ${ }^{1}$ can provide a time-efficient and cost-effective approach to geomatics data collection, especially for topographic surveys and monitoring studies. An SUA can be set up and launched at very short notice, allowing for multiple flights per day. It can also fly autonomously with the help of pre-defined flight paths. Data can be acquired at lower altitudes, without being limited by cloudy conditions, in contrast to manned photogrammetric surveys. Unlike terrestrial-based approaches, an SUA can collect observations over a large study area (3D MAPPING).

Interest in the use of SUA for archaeology is growing. In May this year the Royal Dutch Institute in Rome is organizing a Practicum on Drone Archaeology focused on 'integrating aerial remote sensing in Mediterranean landscape archaeology', performed in theory and in the field. It will provide students with practical skills, from the analysis of historical photographs, satellite and LIDAR data, to flying drones in the field and collecting new aerial images. In the lab, students will learn to process datasets through various software packages (GIS, 3D-modeling using structure from motion etc.). The work will be performed on case studies in southern Italy.

Various sensors can be mounted on an SUA. For example, a LiDAR alongside a compact digital RGB camera or a multispectral/hyperspectral together with an RGB camera, can enable the integration of heterogeneous observations. The amount of devices mounted is dependent on the payload capability of the SUA.

The general workflow entails:

- assessing the geological, archaeological and modern-day setting of the project area

- gathering and processing of data

- evaluation of the metadata

- data visualization

- interpretative mapping

- ground-observation

- interpretation and contextualisation of the results

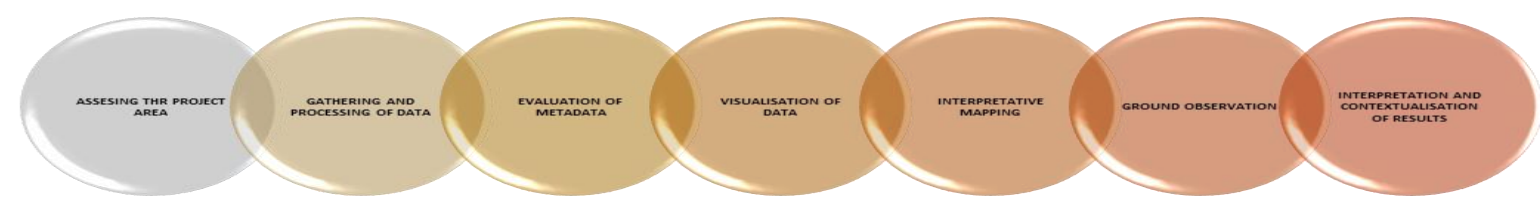

Fig. 20. The workflow chart. Source: the author.

There are many types of SUA and recording devices which can serve the purposes of research. The technology is moving towards miniaturization and lowering of costs. There are different possibilities, technical solutions and producers of SUAs. The HASK research SUA by Heliceo, along with

\footnotetext{
${ }^{1}$ The term Small Unmanned Aircraft (SUA) is used by some Civil Aviation Authorities instead of Unmanned Arial Vehicle (UAV) or 'drone' because the word 'vehicle' implies transportation of some kind and not all SUAs have the capacity to transport a payload. And while the term 'drone' describes the noise they make rather well, the word has negative associations almost everywhere, so is best avoided when trying to get permission to use them. Source: Small Unmanned
} 
survey sets and appropriate software, could serve as a platform for the survey described in this paper ${ }^{2}$.

The Fusion FoxyPro is a VTOL airplane, which means it is characterised by vertical takeoff and landing. It is equipped with 5 blades, with a wingspan of $2 \mathrm{~m}$ and brushless motors. The maximum takeoff weight is $5,5 \mathrm{~kg}$ and the maximum payload $0,3 \mathrm{~kg}$. Its battery, with a load 'on board', lasts for 60 minutes. This SUA can fly at a maximum speed of $120 \mathrm{~km} / \mathrm{h}(75 \mathrm{mph})$ and achieve a distance of $70 \mathrm{~km}$. It makes it possible to scan a surface of approx. $100 \mathrm{ha}$ (247 acres) to $300 \mathrm{ha}$ (741 acres) during a single flight.

A special LiDAR and photogrammetric drone surveyor, the SuperFox6 drone, is fully-automated and has an flight time of 43 minutes. It can carry out a wide range of topographic surveys. The SuperFox6 drone surveyor is designed for large photogrammetric missions. It is also compatible with the new Hélicéo LiDAR System.

This multirotor drone is equipped with 6 blades and brushless motors. The maximum takeoff weight is $10 \mathrm{~kg}$ and the maximum payload is $4 \mathrm{~kg}$. Its battery, with load, lasts for 43 minutes. This SUA can fly at a maximum speed of $50 \mathrm{~km} / \mathrm{h}(75 \mathrm{mph})$ and the control range is up to $10 \mathrm{~km}$. This gives it the possibility of scanning a surface of approx. 150 ha (370 acres) during a single flight. This vehicle is equipped with 2 -axis gyroscope and safety pyrotechnic parachute.

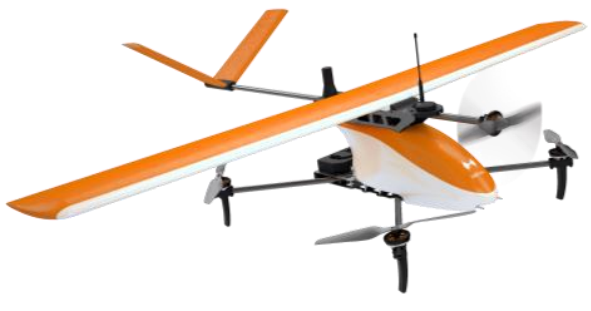

Fig.21. Fusion Foxy Pro. Source HASK.

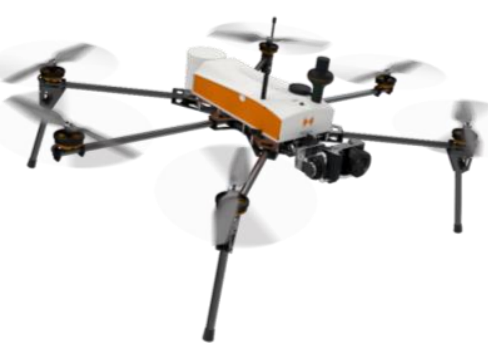

Fig.22. SuperFox6 SUA. Source HASK.

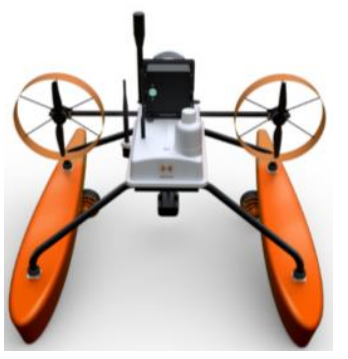

Fig. 23. FoxBathy Catamaran. Source HASK.

For underwater surveys, the SuperBathy catamaran vehicle has been designed. SuperBathy not only helps in monitoring of ports, marinas, sea areas, rivers, creeks, lakes and ponds or lagoons, it also helps to identify critical areas or dangerous objects for navigation. Additionally, it allows periodic monitoring of siltation and supervision of marine sites by performing calculations of cubature and editing DTMs (Digital Terrain Models). This vehicle is fully autonomous if required. It has a cruising time of up to 10 hours and can work within a range of up to 18 linear $\mathrm{km}(9,7 \mathrm{mi})$. The typical cruising speed is 1.0 to $2.0 \mathrm{~m} / \mathrm{s}$ (3.9 knots), but it reaches a maximum speed of $2.5 \mathrm{~m} / \mathrm{s}(4.9$ knots). It is equipped with 2 or 4 underwater engines with floats (depending on float standard) powered by 2 Lithium Polymer batteries and a remote control. The typical surveying area reaches 18 $\mathrm{ha} / \mathrm{h}(45 \mathrm{acres} / \mathrm{h})$ at an average speed of $1.6 \mathrm{~m} / \mathrm{s}$.

The software mounted on board is the Mission Planning HASK Planner with GNSS processing by HASK Geoprocessor. The output data are: Latitude, Longitude, Altitude, according to WGS 84.

It is worth mentioning that HASK software is specified by: high accuracy data georeferencing thanks to the unique algorithm of the HASK GeoProcessor, universal software - the HASK GeoProcessor is designed to work with all Hélicéo's products: all vectors and both DroneBox Slim and RTK, ergonomics - a simple interface, fast and easy to use; the output of the software is a file, with

\footnotetext{
${ }^{2}$ Specification are based on the publication of HELICEO (HASK)
} 
the position of each measure acquired by the sensor and that this file is compatible with different processing software, such as Pix4D or MicMac.

The RTK LiDAR System is an example of a device set used for topographic and anthropogenic land surveys, which can be mounted on SUA and catamarans, as presented above. The system has been developed by Hélicéo for the topography market, the 16-beam (H16) and 32-beam (H32) LiDAR Systems incorporate the industry's best components for LiDAR head, RTK geo positioning and inertial tracking. After 4 years' experience with Trimble GNSS RTK cards, Hélicéo naturally turned to Trimble Applanix cards as well as the Trimble PostPack and RealWorks software suite. The measurement by LiDAR is direct and does not require post-processing. The sensor can survey up to 300,000 points per second and thus cover up to $50 \mathrm{ha}(123 \mathrm{acres})$ in a single flight. It is easily transportable, because the LiDAR technology can be embedded easily onto an SUA, thanks to its light weight. The laser data is accurate to within a few centimeters. This system is integrated with the drone multi-rotor Fox6 from the Hélicéo range of products.

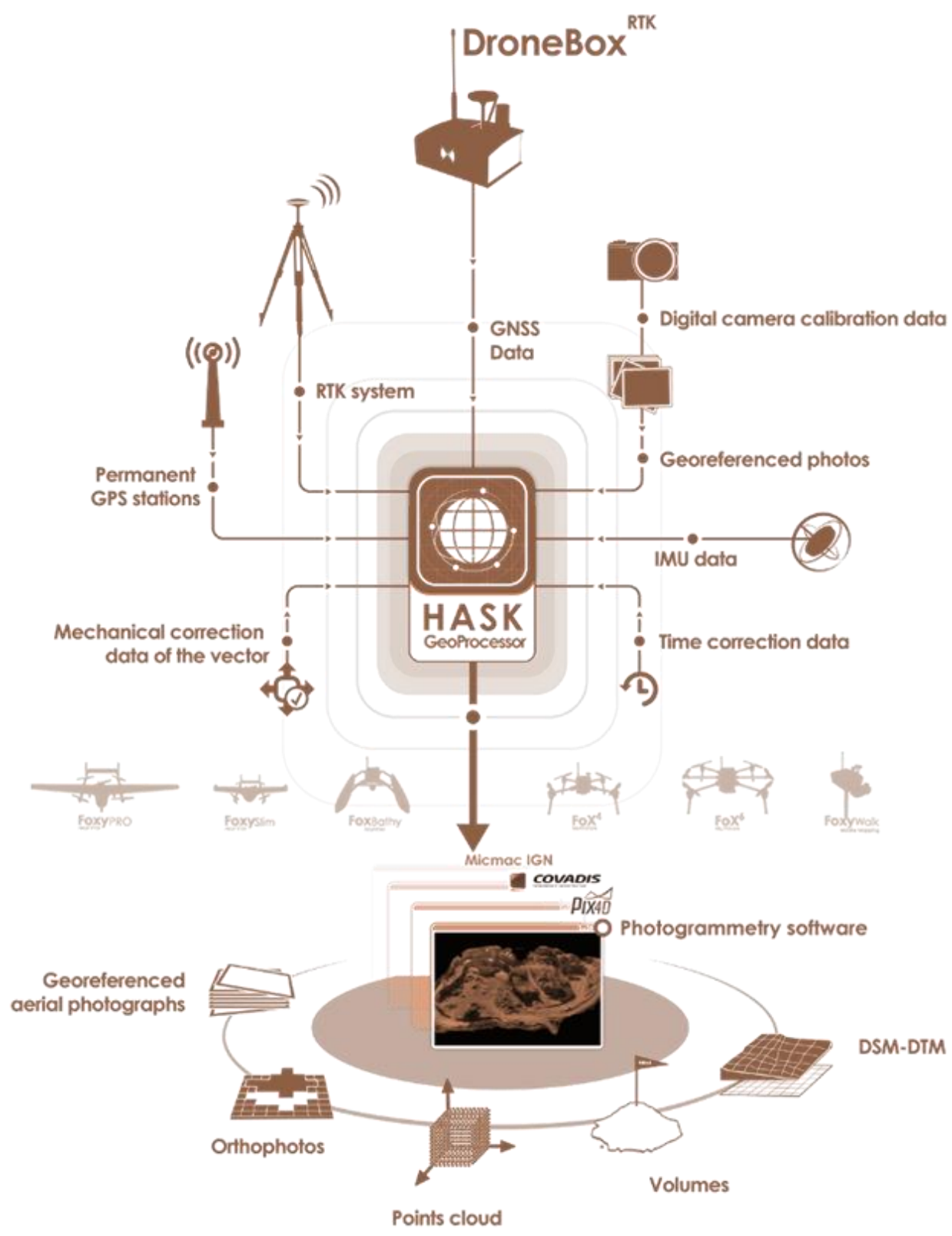

Fig. 24. The HASK GeoProcessor. The output of the software is a file with the position of each measurement acquired by the sensor. This file is compatible with different processing software, such as Pix4D or MicMac. Source: HASK. 


\section{CONCLUSIONS}

The research proved that the -systematic recognition of areas with hidden or exposed, but abandoned, heritage resources using modern technology and survey tools, is better able to protect Mediterranean areas against destructive urban and infrastructural developments and, in the case of monuments not yet discovered and explored, against degradation. There are several benefits to the use of the methods described:

- Heritage protection plans are easier to perform and a database of documents can be established for urban development plans, allowing for the exclusion of areas of historic potential from development. This data could be useful for local spatial planning institutions and in defining areas for new buildings, which would not harm cultural assets and would assist further historical and archaeological research.

- New smart techniques for land surveying allow the non-destructive recognition of potential archaeological sites. Using non-destructive survey methods, it is possible to identify underground and underwater heritage resources, without the need for expensive and long-term physical archaeological exploration.

- The interpretation of the data collected is a subject for further scientific elaboration. The information should be collected on unified digital platforms, and, according to its importance, made available for limited or general access. In accordance with the principle of sustainable development, there is no need to discover and collect all the treasures of cultural heritage that are now hidden from our eyes. We should, however, examine these assets and their range of location and let their hidden treasures exist in situ, properly protected, for future generations.

\section{ACKNOWLEDGEMENTS}

I would like to thank the Dean of the Faculty of Civil Engineering and Architecture of the West Pomeranian University of Technology in Szczecin (Poland) for financial help in the trips to Cyprus and Turkey. Thanks to the implementation of an ERASMUS programme in a partnership between the Faculty of Civil Engineering and Architecture of the West Pomeranian University of Technology in Szczecin in Poland, the Faculty of Architecture of the Gazi University in Ankara and the Faculty of Interior Architecture and Environment at the Izmir University of Economics (both in Turkey), several of the author's study trips have been made possible. Great thanks are also due to Prof. Anastasia Stratigea for organizing the 3rd SmartBlueCity Euro-Mediterranean Conference in 2018 in Larnaca (Cyprus).

\section{BIBLIOGRAPHY}

Conciaioli L., Ocriculum: guida alla citta antica. Archaeological Superintendents of Umbria Region (Italy), 2000

Dietrich, N., Exposed bedrock in Miletus and Priene: an overlooked aspect of Hellenistic and Imperial-era Urbanism. Revue archéologique 2/2016, 62(2), 303-328. doi:10.3917/arch.162.0303; Pp. 303-328. 2016.

Garzia F., Lombardi M., Lucca P., Analysis And Data Acquisition Methodology Based On Flying Drones For The Implementation Of Internet Of Everything To Smart Archaeological Areas, International Journal of Heritage Architecture, Vol. 2 No.3 (2018) p.383-394,access: 27.03.2019 
Grammer B., Draganits E., Gretscher M, Muss U. LiDAR-guided Archaeological Survey of a Mediterranean Landscape: Lessons from the Ancient Greek Polis of Kolophon (Ionia, Western Anatolia). DOI: 10.1002/arp. Archaeol. Prospect. 24, 311-333 (2017). 2017

HASK GeoProcessor http://www.heliceo.com/en/software-for-photogrammetry/direct-georeferencing-gnssdata-hask/, access: 27.03.2019

Hay Sophie. Just an archaeologist who lived in Rome 2013 https://pompei79.wordpress.com/tag/archaeology/ access: 27.03.2019

Open Street Map https://www.openstreetmap.org, access: 27.03.2019

Pleiades project http://pleiades.stoa.org, access: 27.03.2019

Small Unmanned Aircraft (SUA) in HMA https://www.nolandmines.com/small_unmanned_aircraft_in_HMA.html. access: 20.03.2019

The Ionian Dodekapolis with the extra-urban sanctuaries and their Lydian neighbours. Topographic data derived from EU-DEM. http://land.copernicus.eu/in-situ/eu-dem-derived-products/eu-dem, access: 27.03.2019

THE OLDEST SUBMERGED TOWN IN THE WORLD | PAVLOPETRI (2016) https://greecebyagreek.com/2016/06/23/oldest-submerged-town-world-pavlopetri/, access: 27.03.2019

Wessmann. Drawing of the ancient city of Aspendos. 2017. https://commons.wikimedia.org/wiki/File:Aspendos_plan_of_the_ancient_city.jpg. access:28.04.2019

3D MAPPING WITH DRONES - LIDAR CASE STUDY https://www.heliguy.com/blog/2018/06/22/3d-mappingwith-drones-lidar-case-study/, access: 27.03.2019

\section{AUTHOR'S NOTE}

Prof. PhD DSc. Architect works as professor and the Chair of the Department of History and Theory of Architecture at the Faculty of Civil Engineering and Architecture of WPUT in Szczecin. He publishes in the area of his scientific interest enhancing the history and theory of architecture in their different occurrences, heritage protection, urban planning and contemporary architecture.

\section{O AUTORZE}

Prof. zw. dr hab. inż. arch., pracuje na stanowisku profesora i kierownika Katedry Historii i Teorii Architektury na Wydziale Budownictwa i Architektury ZUT w Szczecinie. Publikuje w obszarze swoich zainteresowań naukowych obejmujących historię i teorię architektury w jej różnych przejawach, ochronę dziedzictwa, urbanistykę oraz architekturę współczesną.

Contact | Kontakt: zbigniew.paszkowski@gmail.com 